\title{
Examining fire-prone forest landscapes as coupled human and natural systems
}

\author{
$\underline{\text { Thomas A. Spies }}^{1}$, Eric M. White $^{2}, \underline{\text { Jeffrey D. Kline }}^{1}, \underline{\text { A. Paige Fischer }}^{1}$, Alan Ager $^{1}$, John Bailev $^{2}, \underline{\text { John Bolte }}^{2}, \underline{\text { Jennifer Koch }}^{3}$, \\ Emily Platt $^{2}$, Christine S. Olsen ${ }^{2}$, Derric Jacobs ${ }^{2}$, Bruce Shindler ${ }^{2}$, Michelle M. Steen-Adams $^{4}$ and $^{2}$ Roger Hammer ${ }^{2}$
}

\begin{abstract}
Fire-prone landscapes are not well studied as coupled human and natural systems (CHANS) and present many challenges for understanding and promoting adaptive behaviors and institutions. Here, we explore how heterogeneity, feedbacks, and external drivers in this type of natural hazard system can lead to complexity and can limit the development of more adaptive approaches to policy and management. Institutions and social networks can counter these limitations and promote adaptation. We also develop a conceptual model that includes a robust characterization of social subsystems for a fire-prone landscape in Oregon and describe how we are building an agent-based model to promote understanding of this social-ecological system. Our agent-based model, which incorporates existing ecological models of vegetation and fire and is based on empirical studies of landowner decision-making, will be used to explore alternative management and fire scenarios with land managers and various public entities. We expect that the development of CHANS frameworks and the application of a simulation model in a collaborative setting will facilitate the development of more effective policies and practices for fire-prone landscapes.
\end{abstract}

Key Words: agent-based model; CHANS; coupled human and natural systems; fire policy; fire-prone landscapes

\section{INTRODUCTION}

Coupled human and natural systems (CHANS) or socialecological systems in fire-prone landscapes are characterized by complex interactions between fire-dependent natural systems and nearby rural and urban human communities in which wildfire is viewed as undesirable. Fire-prone landscapes are globally widespread and produce a number of valuable ecosystem services, including wood fiber, fuel, recreation, regulation of carbon emissions, and biodiversity (Noss et al. 2006, Bowman et al. 2009). In many parts of the world, such landscapes are often incompletely characterized as the wildland-urban interface (WUI), a narrow transition zone between unpopulated fireadapted landscapes and populated areas that have elevated risk levels for loss of homes and lives to wildfire. However, the spatial extent of ecological and socioeconomic dynamics of fire-prone landscapes is broader than just the WUI, encompassing the full extent of wildlands in which the WUI is embedded (Pyne 2008).

Fire-prone landscapes exhibit many of the fundamental characteristics of CHANS (Liu et al. 2007). Central among these are complexity and feedbacks, which may be lagged in time and space, and policies that can have unintended consequences or surprises (e.g., effects of wildfire suppression policies of the 20th century; Chapin et al. 2003). Complexity can be defined in different ways; we define it as aggregate complexity, the diverse set of subsystems whose interactions give rise to multiple equilibria, unpredictability, and contingency effects (Manson 2001, Pickett et al. 2005). Social-ecological feedbacks are particularly important drivers of complexity and sustainability of ecosystem services associated with CHANS. For example, actions intended to reduce short-term risk (e.g., fire suppression) can produce positive feedbacks that lead to elevated longer-term risk of loss to high-severity wildfire. This and other maladaptive responses to fire-prone ecosystems have catalyzed destabilizing (positive) feedbacks (Pyne 2010, Lindenmayer et al. 2011, Perry et al. 2012). However, learning and adaptation, mediated by institutions, can generate stabilizing feedbacks (e.g., Lambin et al. 2001). Fire-prone landscapes also are a type of natural hazard system in which concepts of risk and risk management apply but have received little attention in the CHANS literature (McCaffery 2004, but see Turner et al. 2003).

Here, we develop a conceptual framework for understanding and studying fire-prone landscapes as CHANS and illustrate it with an example from a landscape in central and south-central Oregon. Although conceptual frameworks for social-ecological dimensions of fire-prone ecosystems have been outlined through global-scale and historical studies (Bowman et al. 2011, O'Connor et al. 2011), we are not aware of characterizations of contemporary fire-prone landscapes using a CHANS approach that includes a robust treatment of the social subsystems. Such conceptual models are an important first step in identifying information gaps and in building simulation models to explore system behaviors at landscape scales. Landscape models that link vegetation dynamics, management activity, climate, and fire behavior have been developed (O'Connor et al. 2011), but more fully developed conceptual and simulation models that take into account human decision-making and feedbacks from the landscape to the human system are less common (but see Millington et al. 2008). Our first objective is to identify some major challenges for human adaptation in fire-prone landscapes through the lens of CHANS. Our second objective is to use a landscape in Oregon to identify the components and interactions that must be characterized in the development of conceptual and simulation models of these social-ecological systems.

\section{ADAPTATION CHALLENGES AND OPPORTUNITIES}

Knowledge and theory related to CHANS is rapidly developing, but the practice of CHANS modeling is far from mature (Liu et al. 2007). Central elements of theory are rooted in concepts of complexity that challenge traditional notions of stability and predictability that have been the foundation of ecological, economic, and social theory in the past (Scoones 1999, Manson 2001). Instead, complexity theory is based on assumptions of multiple equilibria, unpredictability, and contingency, ideas that mesh with postmodern concepts of the world but are challenging 
to apply in real-world policy and management settings. The integration of ecological and social sciences is central to developing a mature science of CHANS; however, integration has often been lacking (Jacobson and Duff 1998, Scoones 1999). We attempt to take a balanced view, which requires more attention to social sciences than is typical of fire-prone landscape studies.

One of the main reasons to develop more comprehensive models of fire-prone CHANS or social-ecological systems is to improve social-ecological resilience and adaptation strategies. History has shown that fire policies can result in surprises and maladaptive behaviors (e.g., fire suppression effects). We assume that a better understanding of fire-prone landscapes through integration of ecological and social sciences will reduce the likelihood of surprises, improve understanding of system behavior and interactions, and lead to more effective policies and practices.

We next outline three major challenges to adaptation and better policies that lie at the heart of these social-ecological systems. These challenges are not all-encompassing, but do correspond to three major characteristics that are common to all CHANS: heterogeneity, feedbacks, and scale effects (Pickett et al. 2005, Liu et al. 2007). They are also closely related to other CHANS concepts, including nonlinear dynamics with thresholds, time lags, resilience, and surprises. We then discuss how social landscapes, i.e., heterogeneous interacting networks of institutions and people, can promote adaptive policies and behaviors.

\section{Heterogeneity and system complexity: a collision of worlds}

The first major challenge in understanding and promoting adaptation in fire-prone landscapes arises from the juxtaposition of a natural system that is dependent on episodic destruction and regrowth of biomass and local plant and animal populations, and a human system with a preference for stability of structures, predictability of socioeconomic dynamics, and protection of human life. Although this challenge is common to any CHANS that is subject to natural hazards such as flooding or earthquakes, fire-prone landscapes have some distinctive features. For example, whereas human activity can have bearing on the effects of many climate or geological hazards, in the case of fire-prone landscapes, human activity such as vegetation management, wildfire suppression, and fire ignition can have direct and indirect effects on the frequency and severity of the hazard itself (O'Connor et al. 2011). A fundamental characteristic of fire-prone landscapes, i.e., their wildness, both contributes to making them prone to wildfire and is also part of their strong appeal to humans, who potentially place themselves at risk by living in them. The juxtaposition of natural and human subsystems leads to significant complexity as a result of diverse human objectives, behaviors, and policies pertaining to the management of these landscapes.

In the wildland part of fire-prone landscapes, efforts to sustain species and ecosystems are based on maintaining fire regimes and processes (Spies et al. 2012). Many plants, animals, and ecological processes (e.g., site productivity and nutrient cycling) are dependent on specific fire regimes characterized by the severities, sizes, timing, and locations of fire. However, the wildland part of the fire-prone landscape is often not free of human influences. Human activities have had a variety of influences (McWethy et al. 2013) on fire-prone ecosystems. For example, grazing and wildfire suppression have excluded fire from many fire-prone landscapes in the 20th century, changing successional pathways and habitats for processes and species that depend on fire (Keane et al. 2002, Hessburg and Agee 2003, Marlon et al. 2012). Wildfire suppression activities of the past may now be contributing to an increase in area and intensity of fires in some vegetation types as a result of fuel accumulations and changes in climate (Miller et al. 2009). However, this feedback does not operate in all forest types (Schoennagel et al. 2004), making it important that we understand how social-ecological interactions vary across regions and landscapes. We do know that fire is increasing again in regions such as the western United States (Westerling et al. 2006) and southeastern Australia (Lindenmayer et al. 2012), with a variety of ecological consequences, including loss of key habitats (e.g., large old trees and dense old-growth forests that can support endangered species such as the northern spotted owl [Strix occidentalis caurina]) and degradation of water quality. Wildfire also has restored fire-dependent wildlife communities and created habitat diversity (Keane and Karau 2010). The use by the media of terms such as "catastrophic" to describe wildfires can color social perception of fire outcomes, despite most wildfires having a mix of both desirable and undesirable ecological effects (Keane et al. 2008). In other more productive ecosystems, where fire is less frequent and more climate limited than fuel limited, fire suppression activities and fuel treatments may not have had much effect on fire behavior (Littel et al. 2009, McWethy et al. 2013).

The variable and temporally lagged effects of wildfire are a major challenge for land management agencies that seek to manage vegetation, fire, and risk to meet multiple objectives. On the human side, the role and view of wildfire can be quite different. Stability and sustained growth of human communities tends to be a desired condition. Disturbances that destroy property and valued natural resources are generally not considered positive factors that promote stability and sustainable social-ecological systems. However, although natural disasters can have a negative effect on physical capital, they can positively influence human capital and overall economic productivity at the scale of countries (Skidmore and Toya 2002). The response of human communities to the occurrence of, or potential for, disturbance events relates to the concepts of resilience and vulnerability in the human system.

Although resilience has been defined as the ability or capacity of natural communities or ecosystems to be maintained, recover, or adapt to disturbance, there are differences in how these concepts are operationalized in natural and human systems (Adger 2000). Typically, ecologists view resilience in natural systems as maintenance of native species, communities, ecosystem processes, and disturbance regimes within some desirable range (not necessarily historical). Natural systems that shift toward nonnative species or undergo major changes in disturbance regimes are typically not considered ecologically resilient. In general, ecosystems have a strong capacity for adaptation through community change and natural selection, but natural processes might be slower than in human systems and might not keep up with rapidly changing conditions (Folke 2006).

Just as ecologists have argued that resilience depends on diversity in ecological conditions and processes, social scientists posit that a diversity of knowledge, skills, and institutions can help human 
communities recover from and adapt to environmental change (Adger 2000, 2003, Janssen et al. 2006). Moreover, the existence of integrating features of social organization such as norms and networks that enable people to learn, store knowledge and experiences, and engage in creative, flexible decision-making and problem-solving is important to society's ability to respond to problems and recover from disturbances (Adger 2000, Pelling and High 2005). For example, in the WUI, using fire-resistant structures and rebuilding after loss to wildfire can reflect adaptive capacity. At a broader level, community or demographic change may be viewed as a measure of resilience as human communities adapt to new economic and social environments. In-migration of urban people and recreationists into areas with resource extraction-based economies and communities can be seen as an example of how human communities adapt to new economic realities and how diversification of economies can sustain human communities in the face of change. However, questions remain about how the new communities relate to the forest and whether shifts from commodity-based forest economies to recreationbased economies, or some other economy, result in more or less sustainable fire-prone landscapes (Abrams et al. 2012).

\section{Feedbacks in a complex learning environment}

A second major challenge to understanding, modeling, and developing adaptive behaviors in fire-prone landscapes is feedback between natural and human systems. First-order effects of human activities on fire behavior, including fuel treatments, grazing, and fire suppression, are relatively well known (Hessburg and Agee 2003, Agee and Skinner 2005). Less well known is how human decision-makers, including institutions and landowners, respond to ongoing changes in natural systems, including fire hazard (e.g., high fuel loads), fire occurrence, fire effects (gains or losses), and effects of fire exclusion. Conceptually, individuals and entities on the landscape make decisions that reflect the values they place on the rewards (or utility) they receive from specific actions. For example, responses to wildfire experiences can be quite variable within a community and affect subsequent mitigation decisions (McGee et al. 2009, Eriksen and Prior 2011). Forest owners who live on their land are more likely to reduce hazardous fuels than are absentee owners (Fischer 2011). Individuals or companies harvesting timber can receive a reward of revenue from the timber sale (e.g., Joshi and Arano 2009). Conversely, a homeowner owning a forested parcel for its amenity values receives a reward of an attractive view from not harvesting timber or reducing fire hazard (e.g., Nelson et al. 2005). For government entities, the values placed on specific rewards (e.g., revenue from timber harvest, avoiding damage from fire to private property) can be specified in policies established by legislators and administrators. For private companies, the values of rewards may be specified by a board or by company owners; individual landowners determine their own values placed on rewards. Complexity is created as variability in experience and completed actions yields secondary responses in the landscape and creates other feedbacks. Those feedbacks, along with uncertainties related to both outcomes and other decision-making factors, can lead to surprises or cumulative effects that are hard to see until some threshold is crossed.

For any given location in a fire-prone landscape, damaging wildfire typically is a rare event. For example, in many fire-prone forest landscapes, high-severity wildfire may only occur at a given location on average once every $20-100$ years. Most people living or recreating in such landscapes will never personally experience loss or threat from wildfire events that have general annual point probabilities of $\leq 0.05$. Hence, for most actions that people might take to mitigate wildfire risk, such as modifying building materials or vegetative fuels, there may be no opportunity to learn how well specific actions worked. Thus, "the safety benefits of fuel reduction are realized only when a wildfire actually comes, so rewards will be few and lapses rarely punished" (Daniel 2008:115). Often called the "wildfire mitigation paradox" in wildfire risk literature (Steelman and Burke 2007), the problem is exacerbated by temporal lags between human actions and the response of nature. Another problem is that fuel treatment actions and fire suppression do not always reduce fire behavior. The effectiveness of human actions also depends on forest type, time since treatment, and weather (Schoennagel et al. 2004).

If the spatial and temporal scales of the social and ecological systems do not correspond, learning will be difficult (Cumming et al. 2006). Similar to other rural places, human systems in the fire-prone landscapes of the western United States are undergoing demographic and socioeconomic changes. Those underlying changes lead to landscapes with a mix of lifetime and new residents. Mixed tenures in fire-prone landscapes mean that individual residents will have had different opportunities to observe and learn from wildfire experiences. Berkes (2007) reports that social memory can extend at least 20 years in natural hazard systems, but if disturbance intervals are longer and if turnover times of people are shorter, then learning will be difficult. Indeed, longer tenure in an area increases awareness among residents of wildfire and potential effects on human and natural communities (e.g., Gordon et al. 2010, Kyle et al. 2010), and absentee owners are less likely to reduce hazardous fuels than those who reside on or near their land (Fischer 2011). Patterns of differing tenures within fire-prone landscapes can be traced to different types of human communities. Resource-extraction communities (those depending on timber production, grazing, or agriculture) are likely composed mostly of residents with lifetime local-area tenures. Communities experiencing amenity-migration will likely have a more diverse mix of short- and long-tenure residents and might be dominated by those with relatively short local-area tenures (Winkler et al. 2007) who are there for privacy and might be less willing to cooperate with neighbors on hazardous fuel reduction projects (Fischer and Charnley 2012).

Even when there is good knowledge of how human actions influence resource conditions or feedbacks change personal vulnerability, residents may still make decisions that might be considered as undesirable by resource managers and emergency personnel. Such behavior can result from sheer ignorance of potential adverse outcomes, but it also can result from residents making reasoned trade-offs regarding the expected benefits and costs of actions. For example, clearing vegetation to reduce vulnerability to wildfire may incur costs associated with fuel treatment as well as reduced aesthetics and loss of privacy from screening vegetation, which may be perceived by the landowner as outweighing any expected benefits in the form of reduced wildfire vulnerability (e.g., Nelson et al. 2004, 2005, BrenkertSmith et al. 2006). In some cases, residents may believe that treating vegetation produces no benefit in reducing vulnerability to wildfire (e.g., Winter and Fried 2000, Brenkert-Smith et al. 
2006). In some locations, homeowner insurance policies may aid residents in weighing such trade-offs if, for example, a policy requires certain wildfire risk mitigation actions on the part of the homeowner. Alternatively, in the absence of any requirement regarding mitigation action, homeowners might feel reasonably safe as long as their policy covers losses to wildfire.

\section{External drivers}

The third challenge consists of dealing with the effects of biophysical and socioeconomic drivers that are external to the focal landscapes. For example, climate and weather have strong influences over fire regimes and fire behavior (Littell et al. 2010). In many ecosystems, climate change will increase fire frequency by extending the fire season, although the impacts of climate change are variable and uncertain (Westerling et al. 2006, Littell et al. 2010). Fire managers may be able to control wildfire under certain weather conditions, especially where fuel treatments have been conducted or where fuels are naturally limited, but when conditions become less predictable or more extreme, wildfires can be impossible to control and can override effects of topography and fuel treatments (Thompson and Spies 2009, Moritz et al. 2012).

Also at play are external, dynamic socioeconomic factors and processes that influence human behavior in fire-prone landscapes. Many such landscapes are a mixture of resource lands supporting a variety of traditional rural land uses as well as newer residential development. Such an arrangement can have implications for ecological conditions, as well as the interactions between the human and natural systems, as external drivers change demands for traditional rural production. For example, demands for forest and agricultural products are strongly influenced by national and international markets (e.g., Dmitri et al. 2005, Ince et al. 2011). Additionally, new technologies and emerging scarcities regarding renewable electricity and bioenergy can present new opportunities to forest and agricultural landowners (White et al. 2013) and might help to increase the feasibility of some restoration treatments (e.g., White 2010). Finally, many of the costs of production (e.g., fuel and equipment costs) and regulatory requirements facing the timber and agriculture sectors are determined largely by factors external to the focal system.

External demographic changes and economic growth, which can interact with internal socioeconomic and ecological conditions, also can fundamentally alter how land is used within fire-prone landscapes. For example, demand for residential development is dependent on population increases, changes in incomes, preferences for housing, and the number of people per household (White et al. 2009). In addition to increasing the number of residents within the fire-prone landscape, increased demand for housing can significantly drive up the price of rural land (Alig and White 2007), which can act as a powerful incentive for remaining rural landowners to convert additional forest and agricultural lands to housing.

Finally, national and state policies on fire, timber production, restoration activities, development, insurance, etc. also have strong effects on what managers and landowners can do, how success is measured, and the process for learning and change. For example, the national-scale policies of wildfire suppression during the 20th and 21st centuries have contributed to increased fire hazard in many forests, where fuel loads were relatively low under
pre-Euro-American fire regimes. In addition, the U.S. national policy of emphasizing fuel treatments in and around the WUI may draw resources from fire-prone landscape restoration in the wildlands and give homeowners who live in fire-prone forests a false sense of security (Pyne 2010).

\section{Potential role of social networks}

Institutions and social networks can counter the conditions that limit learning, adaptability, and unintended consequences by increasing social memory and promoting communication and actions to improve adaptation and resilience. Community resilience incorporates social concepts, including knowledge, values, social networks, people-place relationships, and others, with agency and self-organizing tendencies (Berkes and Ross 2013). Despite, or because of, the difficult challenges to developing adaptive social-ecological systems in fire-prone landscapes, managers and stakeholders have developed tools and approaches to mitigate losses of values in fire-prone landscapes. These include policies, programs, and institutions that promote wildfire awareness and protection and provide resources for fire hazard reduction, wildfire suppression, and restoration. Federal land management agencies, of course, dedicate large portions of their budgets to wildfire suppression and, to lesser extents, fuel reduction and restoration. Federal agencies also provide funds to state agencies for wildfire suppression and fuel reduction. Federal and state agencies make technical and financial assistance available to landowners and communities at the WUI through programs such as the National Fire Plan's Community Assistance Grant Program and the U.S. Department of Agriculture's Forest Stewardship Program and Environmental Quality Incentive Program (Steelman et al. 2004).

Improving resilience and adaptation requires more than the provision of information and resources to enable land and wildfire management. Social networks and formal and informal institutions that foster communication, problem solving, and collective action also are important to promoting resilience and adaptive capacity (Adger 2000, 2003, Pelling and High 2005, Janssen et al. 2006). Diverse multi-scalar networks of stakeholders working together to redefine problems and forge mutually acceptable solutions may facilitate adaptation. Such networks may promote mechanisms for restoring forest conditions so they are less prone to uncharacteristically destructive wildfire. They also enable coordination of management strategies across social and political boundaries at the scale of many ecological processes.

Some policies, programs, and institutions address resilience and adaptive capacity by creating networks that foster learning, the development of trust, and coordination of management actions. For example, the National Cohesive Wildland Fire Management Strategy engages stakeholders in the coordination of wildfire management across administrative boundaries. The Collaborative Forest Landscape Restoration Program provides funding to local collaborative groups to plan science-based, economically viable fuel reduction and ecological restoration activities on select national forest lands. The Healthy Forest Restoration Act requires that communities receiving fuel reduction funds develop a Community Wildfire Protection Plan. That plan creates a process that convenes residents, property owners, and local, state, and federal agencies to develop strategies for addressing hazardous 
fuel in the WUI (Steelman and Burke 2007, Everett and Fuller 2011). The process of developing community wildfire protection plans and other community wildfire plans (e.g., through Fire Safe Councils in California) has led to many benefits beyond those associated with fuel reduction, including strengthening social networks and building community capacity (Jakes et al. 2007, Everett and Fuller 2011, Steelman and McCaffrey 2013). Most notably, Fire Learning Networks are regional groups that bring together public agencies, tribes, and municipal governments to plan and coordinate fuel reduction and forest restoration activities across ownerships (Butler and Goldstein 2010).

\section{A FIRE-PRONE LANDSCAPE CASE STUDY}

Progress in the theory and application of CHANS concepts will come through development of examples and cross-system synthesis (Liu et al. 2007, Alberti et al. 2011). To reach this goal, critical components and interactions must first be identified for particular landscapes. We use an example from a study in central and south-central Oregon (the Forest People Fire project) to illustrate concepts of aggregate complexity, heterogeneity, feedbacks, and external drivers. We use this example to illustrate how CHANS concepts could be applied in developing conceptual and simulation models for the purpose of improving adaptation in fire-prone landscapes.

\section{Heterogeneity in the ecological and social landscape}

The landscape is characterized by ecological heterogeneity in the form of mountainous topography and steep environmental gradients running from cool, wet, subalpine forests to moist, dry, mixed conifer and pine forests to semi-arid juniper woodlands (Fig. 1). These forest types have different pre-Euro-American fire regimes (Agee 1993) and varying effects of degree of fire exclusion.

Forest ownership patterns are also heterogeneous, but are dominated by federal lands (Fig. 2). Land ownership objectives range from providing wilderness experiences and producing timber to residential homesteads (Table 1). This intermingled and contrasting ecological and socioeconomic landscape increases the likelihood that management actions and wildfire behavior on one ownership will affect ecosystems and human values on other ownerships. For example, wildfires originating in wilderness landscapes have burned old-growth and spotted owl habitat areas at lower elevations and spread into private lands (Spies et al. 2006; Fig. 3).

Historical land-use activities have left a strong imprint on the vegetation and fire regimes. Euro-American activities, which began in the mid-1880s, included grazing, logging, and road building, and disruption and degradation of Native American cultures (Brogan 1940, Robbins 1997). The decline of Native American cultures would also have reduced fire ignitions, though natural ignitions from lightning are common in this region. Although European settlement would have increased fire ignitions in some areas, the amount and frequency of fire in the landscape strongly declined after 1880 (Hessburg and Agee 2003). Studies of existing older pine and mixed conifer patches indicate that the density of shade-tolerant understory trees (e.g., grand fir [Abies grandis] and Douglas-fir [Pseudotsuga menziesii] in some cases) has increased several fold, and the presence of large, old, shade-intolerant pines has been reduced by as much as $70 \%$ as
Fig. 1. Potential vegetation forest community types (late successional plant communities) in the central and southcentral Oregon, USA, study region. Forest vegetation communities that are dependent on frequent (10-50 yr) low- to mixed-severity fire include: mixed conifer dry, Douglas-fir dry, portions of mixed conifer cool/moist, ponderosa pine, and ponderosa pine/lodgepole pine. Fire regimes in other forest vegetation communities have longer return intervals and have been less influenced by human activities. Map derived from the Integrated Landscape Assessment Project (http://oregonstate. edu/inr/ilap).

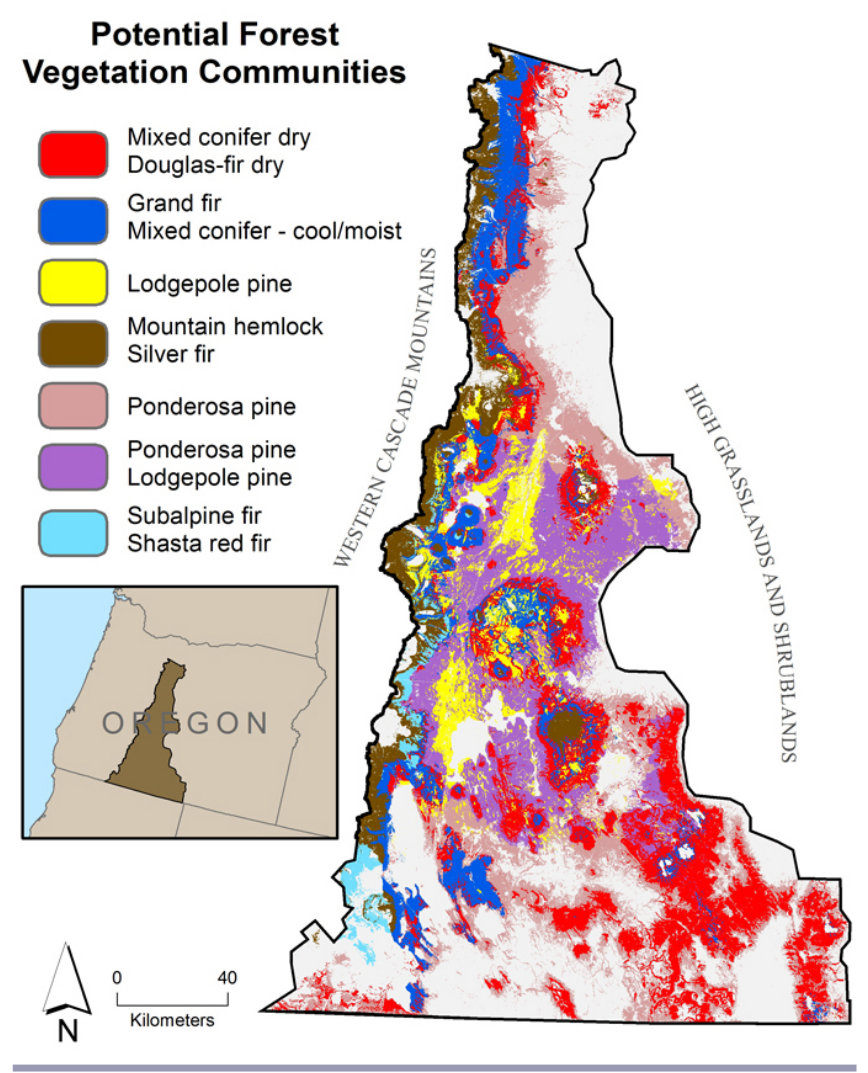

result of partial cutting (Merschel et al. 2014). Increased forest density and homogeneity increases the likelihood of large, highseverity fire and thereby reduces the capacity of the forest to recover from fire.

\section{Feedbacks and actor learning}

Learning about fire in this environment can be challenging for forestland owners, homeowners in the WUI, federal managers, and the public. For example, for the five-year period ending in 2011, we estimate that only $0.4 \%$ of nonindustrial forestland owners in the study area experienced a wildfire on or adjacent to their tax lot based on Monitoring Trends in Burn Severity (MTBS: http://www.mtbs.gov/index.html). In a different study, a greater percentage $(33 \%)$ of private nonindustrial forestland owners in our study area reported having experienced a fire on their parcel in recent years (Fischer 2011). The difference between these analyses could result from the surveyed owners considering both 
Fig. 2. Ownership across the study area and home density in a sub-area where the wildland-urban interface is a prominent component of the landscape. Source of housing data: Oregon Department of Forestry (2006).

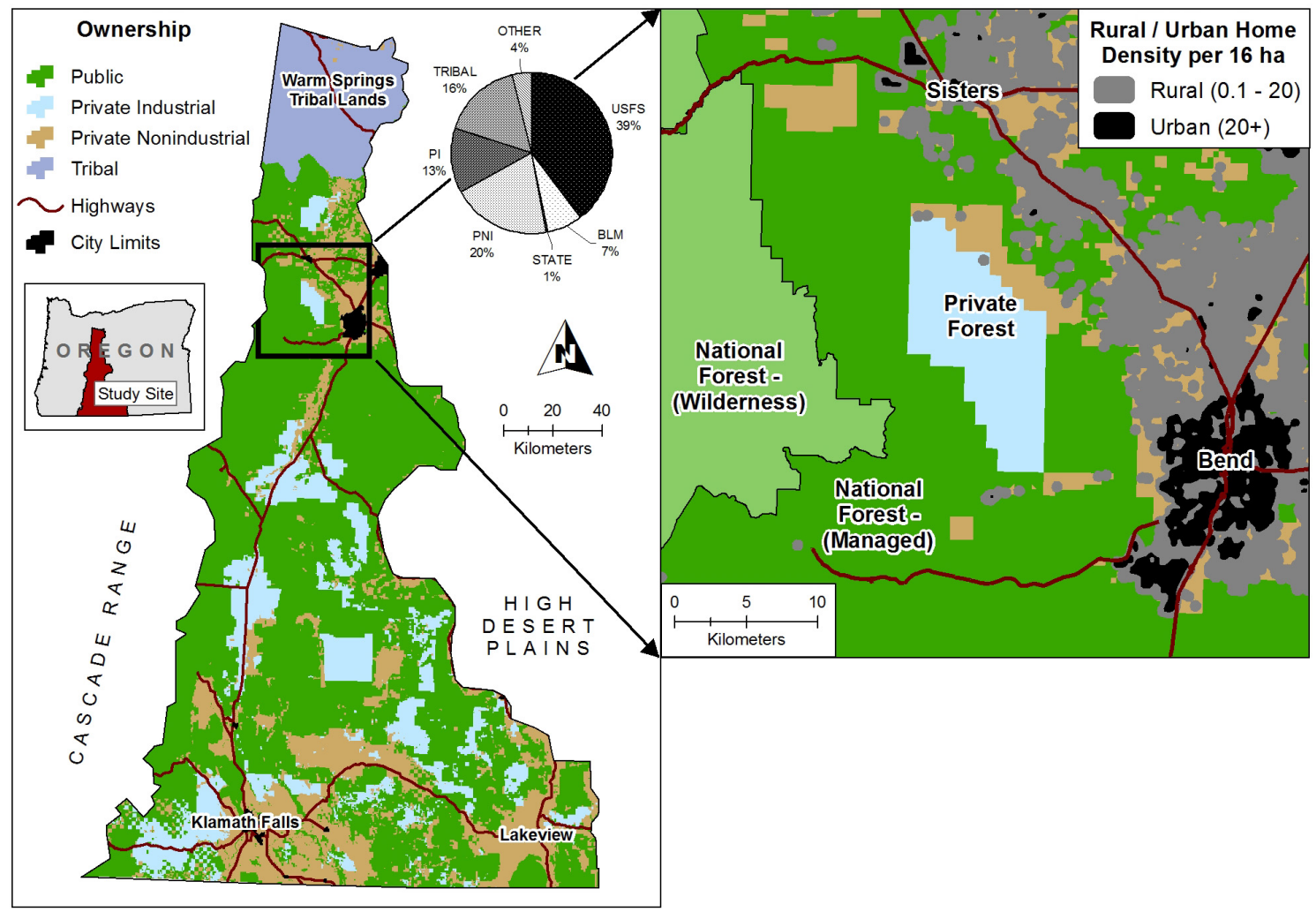

planned and unplanned fires or failure to detect small fires (approximately $<8$ ha in our study area) in the MTBS data. Regardless, with low frequency of fire experience, relatively few people have direct knowledge of how well any fuel treatments or Firewise activities achieve the goal of reducing loss to wildfire. Despite infrequent personal experience with fire, a greater percentage (between 40\% [unpublished data] and 66\% [Fischer 2011]) of nonindustrial forestland owners in our study area reported having undertaken thinning activities to reduce fuel loading. The basis of that decision probably has come from knowledge of fires in the region and from institutions that communicate about risk.

Learning is also made difficult by the varied fire outcomes and differing values of landowners and stakeholders. For example, the ecological consequences of recent fires can be good, bad, or neutral depending on the values that people have; they are not an absolute (Spies et al. 2012). Outcomes that would be considered good by many people include fires that reduce surface and understory fuels, reducing the future chance of high-severity fire, and fires that burn as a fine-grained mosaic of high-severity and low-severity fire, creating habitat for a diverse set of species, including early successional plants, insects, and animals such as high-profile game species like elk (Cervus canadensis roosevelti; Fig. 3C,D). Conversely, undersirable outcomes, which are often associated with high-severity fires, frequently include the loss of homes, such as the 1990 Awbrey Hall fire near Bend that destroyed
22 homes, or the loss of important wildlife habitat, such as the 2003 B \& B fire (Fig. 3B) that burned 11 habitat areas for the threatened northern spotted owl(U.S. Department of Agriculture Forest Service 2005).

\section{External drivers}

Key external drivers in this landscape include housing growth, changing timber markets, demographic shifts, and climate change (Fig. 4). In Deschutes County, the fastest growing county in the study area, total real estate value more than tripled between 2000 and 2008, just before the housing market crash (Economic Development for Central Oregon 2009). During the same period, nominal prices for delivered mid-size ponderosa pine logs declined by $>25 \%$ (Oregon Department of Forestry 2012). The cities of Bend and Sisters in Deschutes County have experienced rapid growth and development, largely based on real estate and recreation, which are a function of both internal and external drivers. Other communities such as Lakeview and Klamath Falls have experienced more limited population growth and still look to forest-related sectors to support the economy. The forest sector contributes $>25 \%$ of the economic base in the southern part of the study area of Klamath and Lake Counties (Oregon Forest Resources Institute 2012). Future trends are likely to continue along these two divergent paths (amenity centric vs. resource production) if, for example, biomass-based economies or restoration-based forest management expands. Or, they might converge if recreation-based economies expand in the south of 
Table 1. Major forest actor groups, ownership goals, actions, and potential factors that might influence their decision-making in central and south-central Oregon, USA. Information is based on published material (e.g., Fischer 2011, Fischer et al. 2014) and interviews with land owners.

\begin{tabular}{|c|c|c|c|}
\hline Actor & Goals & Actions & Influencing factors \\
\hline Public forest managers & $\begin{array}{l}\text { Reduce fire hazard } \\
\text { Ecosystem services provisioning }\end{array}$ & $\begin{array}{l}\text { Manipulate vegetation/fuels } \\
\text { Suppress wildfire } \\
\text { Harvest timber }\end{array}$ & $\begin{array}{l}\text { Costs } \\
\text { Risk perception } \\
\text { Policies/laws } \\
\text { Location of wildland-urban interface } \\
\text { Public acceptance }\end{array}$ \\
\hline Tribes & $\begin{array}{l}\text { Financial returns } \\
\text { Reduce fire hazard } \\
\text { Cultural values }\end{array}$ & Same as above & Same as above \\
\hline Large companies & $\begin{array}{l}\text { Financial returns } \\
\text { Reduce fire hazard }\end{array}$ & $\begin{array}{l}\text { Same as above }+ \\
\text { Resort development }\end{array}$ & $\begin{array}{l}\text { Same as above }+ \\
\text { Prices } \\
\text { Land values }\end{array}$ \\
\hline Nonindustrial & $\begin{array}{l}\text { Amenities } \\
\text { Reduce fire hazard } \\
\text { Financial returns }\end{array}$ & $\begin{array}{l}\text { Same as above }+ \\
\text { Develop land } \\
\text { Firewise }\end{array}$ & $\begin{array}{l}\text { Same as above + } \\
\text { Values } \\
\text { Social networks }\end{array}$ \\
\hline Homeowners & $\begin{array}{l}\text { Amenities } \\
\text { Reduce fire hazard }\end{array}$ & $\begin{array}{l}\text { Firewise } \\
\text { Sell home }\end{array}$ & $\begin{array}{l}\text { Costs } \\
\text { Risk perception } \\
\text { Values } \\
\text { Social networks }\end{array}$ \\
\hline
\end{tabular}

Fig. 3. Patterns of burn severity in the 2003 B \& B fire (A), which burned $>36,000$ ha on the Deschutes and Willamette National Forests, and images of different burn severities (B-D). (B) High-severity burns destroyed old forest and northern spotted owl (Strix occidentalis caurina) habitat but created early successional habitats. (C) Medium-severity and (D) low-severity burns were more characteristic of historical fire severities in the mixed conifer and pine forest types. Images (C) and (D) are from other recent fires in the study area. Severity classes are from U.S. Department of Agriculture Forest Service and U.S. Geological Survey (2009).

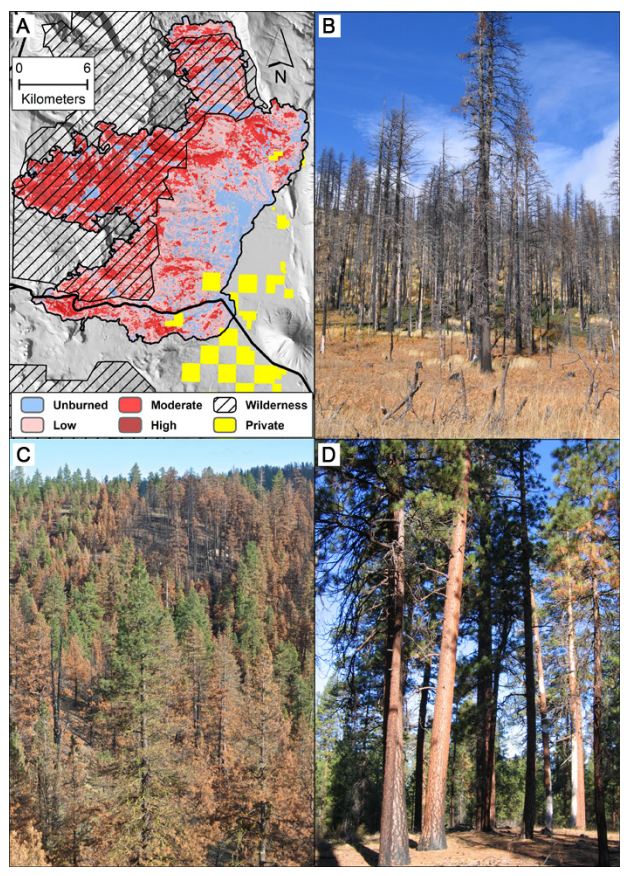

the study region. Climate, another external driver, is expected to increase wildfire frequency in the region (Littell et al. 2010) and increase the number of outbreaks of insects such as the pine beetle, which have variable effects on fuel conditions and potential fire behavior (Hicke et al. 2012).

\section{Factors promoting adaptation and resilience}

The study area seemingly is rich in institutions, social networks, and landscape collaboratives that focus on forest and fire management issues at a variety of scales (Table 2). For example, the Lakeview Stewardship Group facilitates interaction among environmentalists, forest industry, and federal managers to reduce wildfire risk, restore forest structure and composition, and provide timber to local mills. These institutions and others are part of a large, loosely quantified social network that influences land management and landscape change. It is not clear how they interact and affect landscape outcomes when goals might appear to conflict, such as protecting homes from wildfire and promoting wildfire as a natural process that improves ecosystem functions. Social networks might play a role in explaining landowner inclination to conduct vegetation management. Initial research results support the notion of a positive relationship between fuel treatment efforts and connections with conservation and fire organizations (Fischer et al. 2014).

Risk management is another adaptation strategy that uses assessment, mitigation actions, and wildfire suppression activities to reduce the loss of structures and economic and ecological values of forests to wildfire. The Central Oregon Fire Management Service coordinates many of the activities in the project area. At the state level, the Oregon Wildland Fire Protection Program has primary responsibility for wildfire prevention, including risk assessment and wildfire suppression, on private and state forest lands. This mix of landowners and institutions with responsibility for fire risk management creates a complex set of actors with different perspectives on a landscape where fires regularly cross administrative and ecological boundaries. Our social network analysis indicates that the 
Table 2. Typology and examples of institutions, social networks, and collaboratives currently operating in central and south-central Oregon, USA. Information is based on interviews with various stakeholders (P. Fischer, unpublished data).

\begin{tabular}{|c|c|c|}
\hline Organization grouping & Count & Example organizations \\
\hline $\begin{array}{l}\text { Agencies that provide assistance to } \\
\text { landowners and land managers }\end{array}$ & 7 & $\begin{array}{c}\text { Oregon State University extension, Oregon Department of Forestry Private Forests } \\
\text { Division, Natural Resources Conservation Service }\end{array}$ \\
\hline Conservation agencies and groups & 15 & Oregon Wild, Sierra Club, Wilderness Society, Oregon Department of Fish and Wildlife \\
\hline Fire protection agencies and groups & 51 & $\begin{array}{c}\text { Oregon Department of Forestry Fire Protection Division, U.S. Forest Service Fire and } \\
\text { Aviation, Forest Service and Bureau of Land Management Central Oregon Fire } \\
\text { Management Service, rural fire protection districts, municipal fire departments, Project } \\
\text { Wildfire }\end{array}$ \\
\hline Elected government & 10 & State, city, and county elected officials and their staff \\
\hline Research institutions & 12 & $\begin{array}{c}\text { Departments within Oregon State University and University of Oregon, Forest Service } \\
\text { Pacific Northwest Research Station }\end{array}$ \\
\hline $\begin{array}{l}\text { Agencies and groups that focus on } \\
\text { ecological restoration }\end{array}$ & 34 & $\begin{array}{c}\text { Forest Service national forests and ranger districts, The Nature Conservancy, National } \\
\text { Park Service }\end{array}$ \\
\hline $\begin{array}{l}\text { Groups that focus on sustainability } \\
\text { (balancing ecological, economic, and }\end{array}$ & 8 & $\begin{array}{c}\text { Sustainable Northwest, Lake County Resource Initiative, Klamath Lake Forest Health } \\
\text { Partnership }\end{array}$ \\
\hline
\end{tabular}

social goals)

Forest product and management

companies, contracting firms, and

Cascade Timberlands, Jeld Wen Timber and Ranches, Collins Pine Company, Society of interest groups

structure of the fire-protection network and the forest restoration networks are quite different, and the two networks are relatively less connected than would be expected by chance (P. Fischer, unpublished data). The problem of developing cross-ownership and institutional risk management strategies is repeated on wildlands throughout the western United States and is being addressed, in part, by a revised National Cohesive Wildland Fire Management Strategy as mandated in the federal FLAME Act (Federal Land Assistance, Management and Enhancement [FLAME] Act of 2009; Interior, Environment, and Related Agencies Appropriations Act, 2010, Title V). Risk assessment and visualization tools such as Envision will be needed to facilitate these collaborative efforts at landscape scales.

\section{Toward an agent-based model}

Simulation models are increasingly used to further the understanding of social-ecological systems and to support decision-making processes. We now outline the design and elements of the agent-based model we are building for our system. We do not yet have model results, but we have learned much in the design and building phase, which includes developing a conceptual model (Fig. 4), gathering empirical information, and conducting component studies to parameterize the main model. Agent-based simulations are especially attractive in this context because of their intuitive structure based on the analogy between agents and the active elements in the original system (Klügl 2008). Our simulation model is based on the agent-based Envision framework that was designed for the development and analysis of spatially explicit landscape change simulations (Bolte et al. 2007).

Envision uses a "pluggable" architecture that allows the incorporation of other types of models that span ecological, economic, or socio-cultural dimensions. Envision provides a predefined architecture incorporating actors, spatially explicit landscape representations, decision rules, autonomous change processes, landscape production models, and landscape feedbacks. Human behaviors related to land management decision-making are characterized in Envision through the threeway interactions of actors, landscape production, and decisionmaking (Fig. 4).

Actors are land managers (Table 1) that alter the landscape by making decisions about the management of particular areas for which they have management authority. Each of these actors holds different beliefs and values toward the landscape that are represented in the decision-making process. Actors differ in the importance they place on certain landscape products (e.g., timber production, biodiversity, and aesthetics). Moreover, they circulate in different social networks that have the potential to influence their beliefs, values, and landscape objectives, as well as knowledge and perception of wildfire risk (Fischer et al. 2012). The landscape is implemented as a set of spatial units (polygons) based on tax lots and initial vegetation structure and composition. The units range in size from approximately $1-8$ ha and average approximately 3 ha.

"Autonomous" processes are landscape change sub-models that operate alongside human decision-making. Our sub-models include housing expansion, vegetation succession, and occurrence and severity of wildfires. The implementation of vegetation succession, i.e., changes in vegetation composition and structure under different management and disturbance regimes, follows a state-and-transition approach based on expert opinion from local federal ecologists. The simulation of potential wildfire behavior characteristics such as spread rate or flame length is based on the FlamMap model using a Minimum Travel Time approach (Finney 2006). The models for housing expansion and associated WUI growth, vegetation succession, and wildfire are hardcoupled and exchange data dynamically within each simulation step. Climate change, an external driver in our model, is evaluated by inputting different weather streams into the fire module and altering fire behavior.

Landscape production models use metrics to quantify a specific type of system production (e.g., timber production or biodiversity) and provide information that can be fed back into 
Fig. 4. Conceptual model of components and interactions in the coupled human and natural fire-prone system of central and south-central Oregon, USA. Landscape condition is the spatial representation of ecological and socioeconomic outcomes that is dynamic and feeds back to human perceptions, decision-making, and actions in the forest and at home sites.

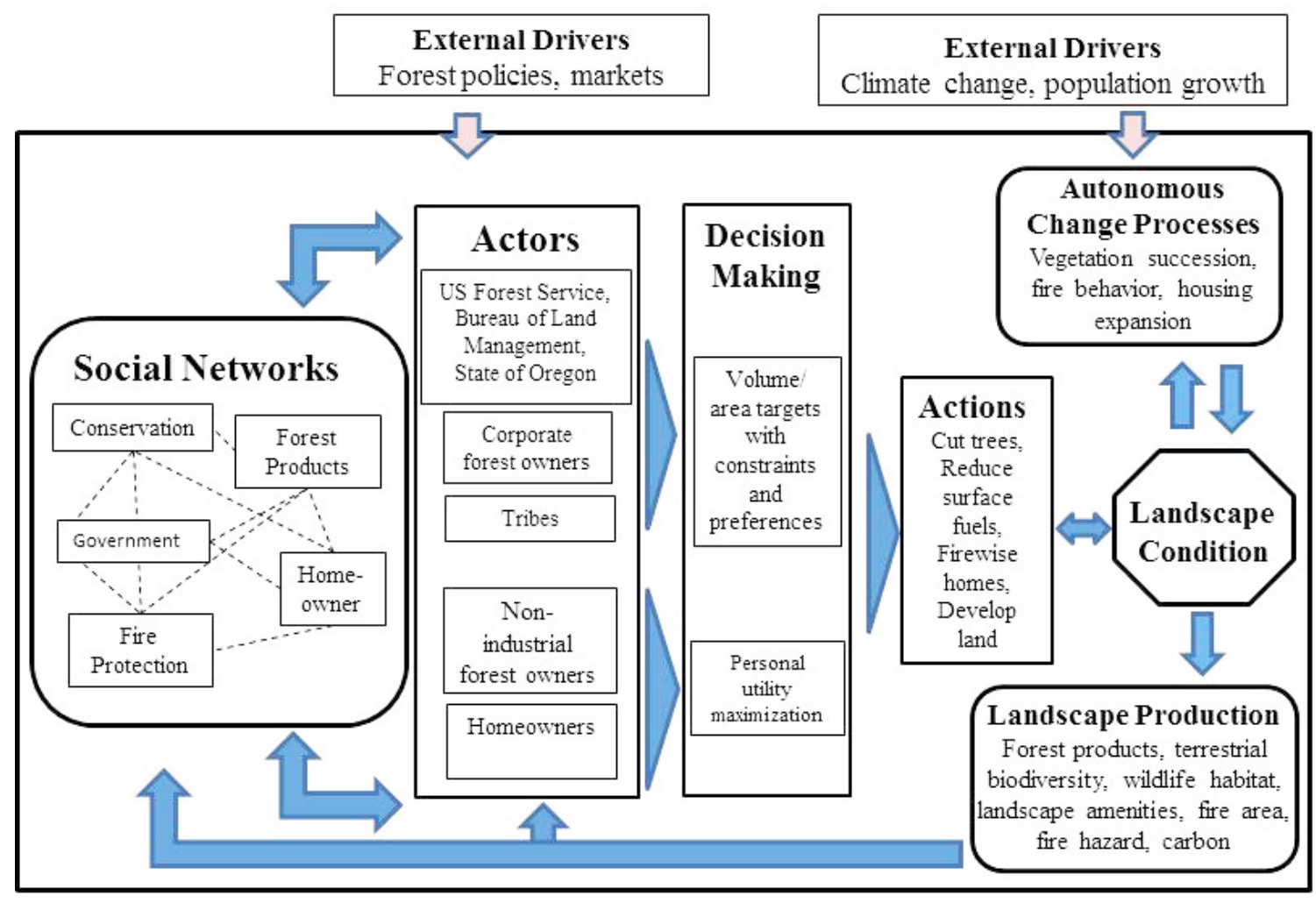

actor decision rule selection and decision-making (Fig. 4). Characterizing emergent scarcity or fire risk to valued system products is an important aspect of Envision. Such scarcity in system production (e.g., declining biodiversity or increasing exposure of homes to fire) is one factor that may influence actor decision-making or social network behavior. Envision allows researchers to define which system products are important for the system under study.

Agent-based models use a variety of methods to simulate human decisions (An 2012). Our model implements two different approaches to actor decision-making. In the target-based approach, actors are attempting to achieve volume production or treatment area targets for actions (e.g., timber harvest) across the landscape for which they have control. Targets are reached by selecting landscape units for treatment based on a ranking subject to pre-defined constraints or preferences. Constraints identify where on the landscape specific actions are disallowed (e.g., mechanical harvesting disallowed within Wilderness areas). Preferences are used to identify spatial units that possess characteristics that are preferred for treatment (e.g., located in proximity to other treated units). Targets, constraints, and preferences used in the target-based approach are identified through landowner interviews and reviews of planning documents. In the utility-maximization approach, statistical models of management behavior are developed based on surveys of landowner management actions. The regression models enable anticipation of landowner management actions (e.g., thinning or reducing flammability of a home and its lot) as a function of landscape, demographic, socioeconomic, and social network variables.

These two different approaches to modeling actor decisionmaking are compatible but have different strengths and weaknesses. Utility maximization is a fundamental theory in microeconomics, and our utility-maximization approach is based on empirical data, hypothesis testing, and revealed behavior but may not capture potential future behavioral relationships under changing landscape conditions. The target-based approach largely is based on information from general knowledge of actor groups and can be a useful alternative when actual data describing actor behavior is limited or when the number of actors is fairly small such as in the case of federal landowners. However, the target-based approach (including constraints and preferences) is more abstract and less based on socioeconomic theory and is reliant on expert judgment rather than tested hypotheses. In both cases, calibration and validation of decision rules and outcomes are difficult, requiring the use of multiple methods (Heckbert et al. 2010), several of which we employ (e.g., surveys, interviews, and historical data). To mitigate the validation problem, we will 
complete outreach efforts with stakeholders to gauge the validity of our results; we will also evaluate how sensitive model outputs are through sensitivity analysis.

We are also investigating how we can incorporate social networks into the Envision model and actor decision-making. This goal is particularly challenging, and we are beginning by characterizing the structure and composition of networks in the region (Table 2) and then building a theoretical network model that will serve as a template for a simulation sub-model within Envision (Fischer et al. 2012).

\section{Interactions with stakeholders and research outcomes}

Feedbacks and learning in our project come at several levels. The first of these comes within the Envision model as described above. The second opportunity arises when we use the model to interact with stakeholders and learn from them about their value systems and decision-making. Finally, feedback gathering and learning comes as the model is used in collaborative settings to facilitate dialog about increasing adaptation and resilience in this fire-prone landscape. Thus, our study is as much a scientific exploration of the behavior of social-ecological systems as a study of research-management-public collaboration and an application of landscape visualization tools in forest planning and management (Castella 2009, Hulse et al. 2009). In the latter use, we have been meeting with various stakeholder groups to help us understand the social-ecological issues they are concerned about and to identify possible scenarios that we could represent in Envision. Issues of concern that have been identified include: (1) potential for a biomass economy to subsidize fuel treatments and restoration, (2) developing and implementing strategies that create more resilient forests in the face of fire and climate change, (3) effects of mill capacity on ability to undertake forest management activities, and (4) effects of government policies (e.g., amount of restoration, emphasis on fuel treatments in the WUI vs. wildlands) on landscape outcomes and ecosystem services. These issues will then be used to develop and explore alternative futures. We expect that our conceptual and simulation models will help identify the most important interactions out of many possible ones, leading to improved understanding of the structure and behavior of these systems not only in research but also in the minds of stakeholders, who need concepts and tools to help them visualize how their individual and collective actions affect ecological and social outcomes across spatial and temporal scales. Ultimately, this could lead to improved polices and management practices that take into account ecological and social landscapes (http://fpf.forestry.oregonstate.edu/home).

\section{CONCLUSIONS}

A CHANS perspective reveals challenges and opportunities for developing adaptive social-ecological systems in fire-prone landscapes. Major challenges include heterogeneity in wildfire behavior and effects, human behavior and values, spatial and temporal lags in wildfire effects, weak landscape feedbacks to humans, and external drivers. The complexities of fire-prone landscapes can create a difficult learning environment for individuals because of lack of personal experience with fire and variable fire effects. Many of these challenges are common to all natural hazard environments. The aggregate complexity that arises from heterogeneity and variable feedbacks between ecosystems and human systems can lead to maladaptive behavior and unintended consequences of fire policies. Social networks and landscape visualization tools that foster communication and learning may help promote more adaptive behavior and policies.

Our conceptual model for a fire-prone landscape in Oregon includes a robust characterization of the social dimensions of the system and identifies key feedbacks that connect the ecological and social subsystems. The model is being used to improve our understanding of the structure of this social-ecological system and to design an agent-based model that can be used to examine interactions and alternative scenarios. Ideally, understanding and modeling this CHANS will enable managers and policy-makers to develop more effective strategies for achieving adaptive socialecological systems in fire-prone landscapes.

Responses to this article can be read online at: http://www.ecologyandsociety.org/issues/responses. $\mathrm{php} / 6584$

\section{Acknowledgments:}

We acknowledge Keith Olsen for preparation of the figures. This research was funded by the National Science Foundation's Coupled Human and Natural Systems Program (NSF Grant CHH-1013296) and the USDA Forest Service PNW Research Station.

\section{LITERATURE CITED}

Abrams, J. B., H. Gosnell, N. J. Gill, and P. J. Klepeis. 2012. Recreating the rural, reconstructing nature: an international literature review of the environmental implications of amenity migration. Conservation and Society 10(3):270-284. http://dx.doi. org/10.4103/0972-4923.101837

Adger, W. N. 2000. Social and ecological resilience: are they related? Progress in Human Geography 24(3):347-364. http://dx. doi.org/10.1191/030913200701540465

Adger, W. N. 2003. Social capital, collective action, and adaptation to climate change. Economic Geography 79 (4):387-404. http://dx.doi.org/10.1111/j.1944-8287.2003.tb00220. $\underline{x}$

Agee, J. K. 1993. Fire ecology of Pacific Northwest forests. Island Press, Washington, D.C., USA.

Agee, J. K., and C. N. Skinner. 2005. Basic principles of forest fuel reduction treatments. Forest Ecology and Management 211 (1-2):83-96. http://dx.doi.org/10.1016/j.foreco.2005.01.034

Alberti, M., H. Asbjornsen, L. A. Baker, N. Brozovic, L. E. Drinkwater, S. A. Drzyzga, C. A. Jantz, J. Fragoso, D. S. Holland, T. A. Kohler, J. Liu, W. J. McConnell, H. D. G. Maschner, J. D. A. Millington, M. Monticino, G. Podestá, R. G. Pontius, Jr., C. L. Redman, N. J. Reo, D. Sailor, and G. Urquhart. 2011. Research on coupled human and natural systems (CHANS): approach, challenges, and strategies. Bulletin of the Ecological Society of America 92(2):218-228. http://dx.doi.org/10.1890/0012-9623-92.2.218 
Alig, R. J., and E. M. White. 2007. Projections of forestland and developed land areas in western Washington. Western Journal of Applied Forestry 22(1):29-35.

An, L. 2012. Modeling human decisions in coupled human and natural systems: review of agent-based models. Ecological Modelling 229:25-36. http://dx.doi.org/10.1016/j.ecolmodel.2011.07.010

Berkes, F. 2007. Understanding uncertainty and reducing vulnerability: lessons from resilience thinking. Natural Hazards 41(2):283-295. http://dx.doi.org/10.1007/s11069-006-9036-7

Berkes, F., and H. Ross. 2013. Community resilience: toward an integrated approach. Society and Natural Resources 26(1):5-20. http://dx.doi.org/10.1080/08941920.2012.736605

Bolte, J. P., D. W. Hulse, S. V. Gregory, and C. Smith. 2007. Modeling biocomplexity - actors, landscapes and alternative futures. Environmental Modelling and Software 22(5):570-579. http://dx.doi.org/10.1016/j.envsoft.2005.12.033

Bowman, D. M. J. S., J. K. Balch, P. Artaxo, W. J. Bond, J. M. Carlson, M. A. Cochrane, C. M. D’Antonio, R. S. DeFries, J. C. Doyle, S. P. Harrison, F. H. Johnston, J. E. Keeley, M. A. Krawchuk, C. A. Kull, J. B. Marston, M. A. Moritz, I. C. Prentice, C. I. Roos, A. C. Scott, T. W. Swetnam, G. R. van der Werf, and S. J. Pyne. 2009. Fire in the earth system. Science 324 (5926):481-484. http://dx.doi.org/10.1126/science.1163886

Bowman, D. M. J. S., J. Balch, P. Artaxo, W. J. Bond, M. A. Cochrane, C. M. D’Antonio, R. DeFries, F. H. Johnston, J. E. Keeley, M. A. Krawchuk, C. A. Kull, M. Mack, M. A. Moritz, S. Pyne, C. I. Roos, A. C. Scott, N. S. Sodhi, and T. W. Swetnam. 2011. The human dimension of fire regimes on earth. Journal of Biogeography 38(12):2223-2236. http://dx.doi.org/10.1111/ j.1365-2699.2011.02595.x

Brenkert-Smith, H., P. A. Champ, and N. Flores. 2006. Insights into wildfire mitigation decisions among wildland-urban interface residents. Society and Natural Resources 19(8):759-768. http://dx.doi.org/10.1080/08941920600801207

Brogan, P. F. 1940. East of the Cascades. Binford and Mort, Hillsboro, Oregon, USA.

Butler, W. H., and B. E. Goldstein. 2010. The US Fire Learning Network: springing a rigidity trap through multiscalar collaborative networks. Ecology and Society 15(3): 21. [online] URL: http://www.ecologyandsociety.org/vol15/iss3/art21/.

Castella, J.-C. 2009. Assessing the role of learning devices and geovisualisation tools for collective action in natural resource management: experiences from Vietnam. Journal of Environmental Management 90(2):1313-1319. http://dx.doi.org/10.1016/j. jenvman.2008.07.010

Chapin, F. S. III, T. S. Rupp, A. M. Starfield, L. DeWilde, E. S. Zavaleta, N. Fresco, J. Henkelman, and A. D. McGuire. 2003. Planning for resilience: modeling change in human-fire interactions in the Alaskan boreal forest. Frontiers in Ecology and the Environment 1(5):255-261. http://dx.doi.org/10.1890/1540-9295 (2003)001[0255:PFRMCI]2.0.CO;2

Cumming, G. S., D. H. M. Cumming, and C. L. Redman. 2006. Scale mistmatches in social-ecological systems: causes, consequences and solutions. Ecology and Society 11(1): 14. [online] URL: http://www.ecologyandsociety.org/vol11/iss1/ art14/.

Daniel, T. C. 2008. Managing individual response: lessons from public health risk behavioral research. Pages 103-116 in W. E. Martin, C. Raish, and B. Kent, editors. Wildfire risk: human perceptions and management implications. Resources for the Future, Washington, D.C., USA.

Dmitri, C., A. Effland, and N. Conklin. 2005. The 20th century transformation of U.S. agriculture and farm policy. Economic Information Bulletin Number 3. U.S. Department of Agriculture, Washington, D.C., USA. [online] URL: http://www.ers.usda.gov/ publications/eib-economic-information-bulletin/eib3.aspx.

Economic Development for Central Oregon. 2009. 2009 central Oregon area profile. EDCO, Bend, Oregon, USA. [online] URL: http://www.edcoinfo.com/CEDocuments/Downloads GetFile.aspx? $\underline{\mathrm{id}=360978 \& \mathrm{fd}=0 \text {. }}$

Eriksen, C., and T. Prior. 2011. The art of learning: wildfire, amenity migration and local environmental knowledge. International Journal of Wildland Fire 20(4):612-624. http://dx. doi.org/10.1071/WF10018

Everett, Y., and M. Fuller. 2011. Fire safe councils in the interface. Society and Natural Resources 24(4):319-333. http://dx.doi. org/10.1080/08941920903313835

Finney, M. A. 2006. An overview of FlamMap fire modeling capabilities. Pages 213-220 in P. L. Andrews and B. W. Butler, editors. Fuels management-how to measure success: conference proceedings. Proceedings RMRS-P-41. U.S. Department of Agriculture Forest Service, Fort Collins, Colorado, USA. [online] URL: http://www.iawfonline.org/pdf/fuels/contents.pdf.

Fischer, A. P. 2011. Reducing hazardous fuels on nonindustrial private forests: factors influencing landowner decisions. Journal of Forestry 109(5):260-266.

Fischer, A. P., A. Callahan, J. Koch, T. A. Spies, C. S. Olsen, E. M. White, and D. Jacobs. 2012. Using an agent-based social network model to investigate interactions between social and ecological systems: early reflections on the forest, people, fire project. Practicing Anthropology 35(1):8-13.

Fischer, A. P., and S. Charnley. 2012. Risk and cooperation: managing hazardous fuel in mixed ownership landscapes. Environmental Management 49(6):1192-1207. http://dx.doi. org/10.1007/s00267-012-9848-Z

Fischer, A. P., J. D. Kline, A. A. Ager, S. Charnley, and K. A. Olsen. 2014. Objective and perceived wildfire risk and its influence on private forest landowners' fuel reduction activities in Oregon's (USA) ponderosa pine region. International Journal of Wildland Fire 23(1):143-153. http://dx.doi.org/10.1071/WF12164

Folke, C. 2006. Resilience: the emergence of a perspective for social-ecological systems analyses. Global Environmental Change 16(3):253-267. http://dx.doi.org/10.1016/j.gloenvcha.2006.04.002

Gordon, J. S., D. Matarrita-Cascante, R. C. Stedman, and A. E. Luloff. 2010. Wildfire perception and community change. Rural Sociology 75(3):455-477. http://dx.doi.org/10.1111/j.1549-0831.2010.00021. $\underline{x}$ 
Heckbert, S., T. Baynes, and A. Reeson. 2010. Agent-based modeling in ecological economics. Annals of the New York Academy of Sciences 1185:39-53. http://dx.doi.org/10.1111/ j.1749-6632.2009.05286.x

Hessburg, P. F., and J. K. Agee. 2003. An environmental narrative of Inland Northwest United States forests, 1800-2000. Forest Ecology and Management 178(1-2):23-59. http://dx.doi. org/10.1016/S0378-1127(03)00052-5

Hicke, J. A., M. C. Johnson, J. L. Hayes, and H. K. Preisler. 2012. Effects of bark beetle-caused tree mortality on wildfire. Forest Ecology and Management 271:81-90. http://dx.doi.org/10.1016/j. foreco.2012.02.005

Hulse, D. W., A. Branscomb, C. Enright, and J. P. Bolte. 2009. Anticipating floodplain trajectories: a comparison of two alternative futures approaches. Landscape Ecology 24 (8):1067-1090. http://dx.doi.org/10.1007/s10980-008-9255-2

Ince, P. J., A. D. Kramp, K. E. Skog, D.-I. Yoo, and V. A. Sample. 2011. Modeling future U.S. forest sector market and trade impacts of expansion in wood energy consumption. Journal of Forest Economics 17(2):142-156. http://dx.doi.org/10.1016/j.jfe.2011.02.007

Jacobson, S. K., and M. D. Duff. 1998. Training idiot savants: the lack of human dimensions in conservation biology. Conservation Biology 12(2):263-267. http://dx.doi.org/10.1111/j.1523-1739.1998.97235. $\underline{\mathrm{x}}$

Jakes, P. J., L. Kruger, M. Monroe, K. Nelson, and V. Sturtevant. 2007. Improving wildfire preparedness: lessons from communities across the U.S. Human Ecology Review 14(2):182-191.

Janssen, M. A., Ö. Bodin, J. M. Anderies, T. Elmqvist, H. Ernstson, R. R. J. McAllister, P. Olsson, and P. Ryan. 2006. Toward a network perspective on the resilience of socialecological systems. Ecology and Society 11(1): 15. [online] URL: http://www.ecologyandsociety.org/vol11/iss1/art15/.

Joshi, S., and K. G. Arano. 2009. Determinants of private forest management decisions: a study on West Virginia NIPF landowners. Forest Policy and Economics 11(2):118-125. http:// dx.doi.org/10.1016/j.forpol.2008.10.005

Keane, R. E., J. K. Agee, P. Fulé, J. E. Keeley, C. Key, S. G. Kitchen, R. Miller, and L. A. Schulte. 2008. Ecological effects of large fires on US landscapes: benefit or catastrophe? International Journal of Wildland Fire 17(6):696-712. http://dx.doi.org/10.1071/ $\underline{\mathrm{WF} 07148}$

Keane, R. E., and E. Karau. 2010. Evaluating the ecological benefits of wildfire by integrating fire and ecosystem simulation models. Ecological Modelling 221(8):1162-1172. http://dx.doi. org/10.1016/j.ecolmodel.2010.01.008

Keane, R. E., K. C. Ryan, T. T. Veblen, C. D. Allen, J. Logan, and B. Hawkes. 2002. Cascading effects of fire exclusion in Rocky Mountain ecosystems: a literature review. General Technical Report RMRS-GTR-91. U.S. Department of Agriculture Forest Service, Fort Collins, Colorado, USA. [online] URL: http://www. fs.fed.us/rm/pubs/rmrs gtr091.html.

Klügl, F. 2008. A validation methodology for agent-based simulations. Pages 39-43 in L. M. Liebrock, editor. $S A C$ '08: Proceedings of the 2008 ACM symposium on applied computing.
ACM, New York, New York, USA. http://dx.doi. org/10.1145/1363686.1363696

Kyle, G. T., G. L. Theodori, J. D. Absher, and J. Jun. 2010. The influence of home and community attachment on firewise behavior. Society and Natural Resources 23(11):1075-1092. http:// dx.doi.org/10.1080/08941920902724974

Lambin E. F., B. L. Turner, H. J. Giest, S. B. Agbola, A. Angelsen, J. W. Bruce, O. T. Coomes, R. Dirzo, G. Fischer, C. Folke, P. S. George, K. Homewood, J. Imbernon, R. Leemans, X. Li, E. F. Moran, M. Mortimore, P. S. Ramakrishnan, J. F. Richards, H. Skånes, W. Steffen, G. D. Stone, U. Svedin, T. A. Veldkamp, C. Vogel, and J. Xu. 2001. The causes of land-use and land-cover change: moving beyond the myths. Global Environmental Change 11(4):261-269. http://dx.doi.org/10.1016/S0959-3780(01)00007-3

Lindenmayer, D. B., W. Blanchard, L. McBurney, D. Blair, S. Banks, G. E. Likens, J. F. Franklin, W. F. Laurance, J. A. R. Stein, and P. Gibbons. 2012. Interacting factors driving a major loss of large trees with cavities in a forest ecosystem. PLoS One 7(10): e41864. http://dx.doi.org/10.1371\%2Fjournal.pone.0041864

Lindenmayer, D. B., R. J. Hobbs, G. E. Likens, C. J. Krebs, and S. C. Banks. 2011. Newly discovered landscape traps produce regime shifts in wet forests. Proceedings of the National Academy of Sciences 108(38):15887-15891. http://dx.doi.org/10.1073/ pnas. 1110245108

Littell, J. S., D. McKenzie, D. L. Peterson, and A. L. Westerling. 2009. Climate and wildfire area burned in western U.S. ecoprovinces, 1916-2003. Ecological Applications 19(4):1003-1021. http://dx.doi.org/10.1890/07-1183.1

Littell, J. S., E. E. Oneil, D. McKenzie, J. A. Hicke, J. A. Lutz, R. A. Norheim, and M. M. Elsner. 2010. Forest ecosystems, disturbance, and climatic change in Washington State, USA. Climatic Change 102(1-2):129-158. http://dx.doi.org/10.1007/ s10584-010-9858-X

Liu, J., T. Dietz, S. R. Carpenter, M. Alberti, C. Folke, E. Moran, A. N. Pell, P. Deadman, T. Kratz, J. Lubchenco, E. Ostrom, Z. Ouyang, W. Provencher, C. L. Redman, S. H. Schneider, and W. W. Taylor. 2007. Complexity of coupled human and natural systems. Science 317(5844):1513-1516. http://dx.doi.org/10.1126/ science. 1144004

Manson, S. M. 2001. Simplifying complexity: a review of complexity theory. Geoforum 32(3):405-414. http://dx.doi. org/10.1016/S0016-7185(00)00035-X

Marlon, J. R., P. J. Bartlein, D. G. Gavin, C. J. Long, R. S. Anderson, C. E. Briles, K. J. Brown, D. Colombaroli, D. J. Hallett, M. J. Power, E. A. Scharf, and M. K. Walsh. 2012. Long-term perspective on wildfires in the western USA. Proceedings of the National Academy of Sciences 109(9):E535-E543. http://dx.doi. org/10.1073/pnas.1112839109

McCaffrey, S. 2004. Thinking of wildfire as a natural hazard. Society and Natural Resources 17(6):509-516. http://dx.doi. org/10.1080/08941920490452445

McGee, T. K., B. L. McFarlane, and J. Varghese. 2009. An examination of the influence of hazard experience on wildfire risk perceptions and adoption of mitigation measures. Society and 
Natural Resources 22(4):308-323. http://dx.doi.org/10.1080/08941920801910765

McWethy, D. B., P. E. Higuera, C. Whitlock, T. T. Veblen, D. M. J. S. Bowman, G. J. Cary, S. G. Haberle, R. E. Keane, B. D. Maxwell, M. S. McGlone, G. L. W. Perry, J. M. Wilmshurst, A. Holz, and A. J. Teply. 2013. A conceptual framework for predicting temperate ecosystem sensitivity to human impacts on fire regimes. Global Ecology and Biogeography 22(8):900-912. http://dx.doi.org/10.1111/geb.12038

Merschel, A. G., T. A. Spies, and E. K. Heyerdahl. 2014. Mixed conifer forests in central Oregon: effects of logging and fire exclusion vary with environment. Ecological Applications, in press.

Miller, J. D., H. D. Safford, M. Crimmins, and A. E. Thode. 2009. Quantitative evidence for increasing forest fire severity in the Sierra Nevada and southern Cascade Mountains, California and Nevada, USA. Ecosystems 12(1):16-32. http://dx.doi.org/10.1007/ $\underline{\mathrm{s} 10021-008-9201-9}$

Millington, J., R. Romero-Calcerrada, J. Wainwright, and G. Perry. 2008. An agent-based model of Mediterranean agricultural land-use/cover change for examining wildfire risk. Journal of Artificial Societies and Social Simulation 11(4): 4. [online] URL: http://jasss.soc.surrey.ac.uk/11/4/4.html.

Moritz, M. A., M.-A. Parisien, E. Battlori, M. A. Krawchuk, J. Van Dorn, D. J. Ganz, and K. Hayhoe. 2012. Climate change and disruptions to global fire activity. Ecosphere 3(6): $\operatorname{art} 49$. http://dx. doi.org/10.1890/ES11-00345.1 http://dx.doi.org/10.1890/ES11-00345.1

Nelson, K. C., M. C. Monroe, and J. F. Johnson. 2005. The look of the land: homeowner landscape management and wildfire preparedness in Minnesota and Florida. Society and Natural Resources 18(4):321-336. http://dx.doi.org/10.1080/08941920590915233

Nelson, K. C., M. C. Monroe, J. F. Johnson, and A. Bowers. 2004. Living with fire: homeowner assessment of landscape values and defensible space in Minnesota and Florida, USA. International Journal of Wildland Fire 13(4):413-425. http://dx.doi.org/10.1071/ $\underline{\mathrm{WF} 03067}$

Noss, R. F., J. F. Franklin, W. L. Baker, T. Schoennagel, and P. B. Moyle. 2006. Managing fire-prone forests in the western United States. Frontiers in Ecology and the Environment 4(9):481-487. http://dx.doi.org/10.1890/1540-9295(2006)4[481:MFFITW]2.0.CO;2

O’Connor, C. D., G. M. Garfin, D. A. Falk, and T. W. Swetnam. 2011. Human pyrogeography: a new synergy of fire, climate and people is reshaping ecosystems across the globe. Geography Compass 5(6):329-350. http://dx.doi.org/10.1111/j.1749-8198.2011.00428. $\underline{\mathrm{x}}$

Oregon Department of Forestry. 2006. Communities at risk: population density. Oregon Department of Forestry, Salem, Oregon, USA. [online] URL: http://www.oregon.gov/DAS/CIO/ GEO/pages/alphalist.aspx.

Oregon Department of Forestry. 2012. Log price informationdomestically processed logs. Oregon Department of Forestry, Salem, Oregon, USA. [online] URL: http://www.oregon.gov/odf/ STATE FORESTS/TIMBER SALES/Yearly-Pond-Values-2012. xls.
Oregon Forest Resources Institute. 2012. The 2012 forest report: an economic assessment of Oregon's forest and wood products manufacturing sector. Oregon Forest Resources Institute, Portland, Oregon, USA. [online] URL: www.theforestreport.org/ downloads/2012 Forest Report.pdf.

Pelling, M., and C. High. 2005. Understanding adaptation: What can social capital offer assessments of adaptive capacity? Global Environmental Change 15(4):308-319. http://dx.doi.org/10.1016/ j.gloenvcha.2005.02.001

Perry, G. L. W., J. M. Wilmshurst, M. S. McGlone, D. B. McWethy, and C. Whitlock. 2012. Explaining fire-driven landscape transformation during the Initial Burning Period of New Zealand's prehistory. Global Change Biology 18(5):1609-1621. http://dx.doi.org/10.1111/j.1365-2486.2011.02631.x

Pickett, S. T. A., M. L. Cadenasso, and J. M. Grove. 2005. Biocomplexity in coupled natural-human systems: a multidimensional framework. Ecosystems 8(3):225-232. http:// dx.doi.org/10.1007/s10021-004-0098-7

Pyne, S. J. 2008. Spark and sprawl: a world tour. Forest History Today Fall 2008:4-11. [online] URL: http://www.foresthistory. org/publications/FHT/FHTFall2008/Pyne.pdf.

Pyne, S. J. 2010. America's fires: a historical context for policy and practice. Forest History Society, Durham, North Carolina, USA.

Robbins, W. G. 1997. Landscapes of promise: the Oregon story, 1800-1940. University of Washington Press, Seattle, Washington, USA.

Schoennagel, T., T. T. Veblen, and W. H. Romme. 2004. The interaction of fire, fuels, and climate across Rocky Mountain forests. BioScience 54(7):661-676. http://dx.doi.org/10.1641/0006-3568 (2004)054[0661:TIOFFA]2.0.CO;2

Scoones, I. 1999. New ecology and the social sciences: what prospects for a fruitful engagement? Annual Review of Anthropology 28:479-507. http://dx.doi.org/10.1146/annurev. anthro.28.1.479

Skidmore, M., and H. Toya. 2002. Do natural disasters promote long-run growth? Economic Inquiry 40(4):664-687. http://dx.doi. org/10.1093/ei/40.4.664

Spies, T. A., M. A. Hemstrom, A. Youngblood, and S. Hummel. 2006. Conserving old-growth forest diversity in disturbanceprone landscapes. Conservation Biology 20(2):351-362. http://dx. doi.org/10.1111/j.1523-1739.2006.00389.x

Spies, T. A., D. B. Lindenmayer, A. M. Gill, S. L. Stephens, and J. K. Agee. 2012. Challenges and a checklist for biodiversity conservation in fire-prone forests: perspectives from the Pacific Northwest of USA and southeastern Australia. Biological Conservation 145(1):5-14. http://dx.doi.org/10.1016/j.biocon.2011.09.008

Steelman, T. A., and C. A. Burke. 2007. Is wildfire policy in the United States sustainable? Journal of Forestry 105(2):67-72.

Steelman, T. A., G. Kunkel, and D. Bell. 2004. Federal and state influence on community responses to wildfire threats: Arizona, Colorado, and New Mexico. Journal of Forestry 102(6):21-27.

Steelman, T. A., and S. McCaffrey. 2013. Best practices in risk and crisis communication: implications for natural hazards 
management. Natural Hazards 65(1):683-705. http://dx.doi. org/10.1007/s11069-012-0386-Z

Thompson, J. R., and T. A. Spies. 2009. Vegetation and weather explain variation in crown damage within a large mixed-severity wildfire. Forest Ecology and Management 258(7):1684-1694. http://dx.doi.org/10.1016/j.foreco.2009.07.031

Turner, B. L. II, R. E. Kasperson, P. A. Matson, J. J. McCarthy, R. W. Corell, L. Christensen, N. Eckley, J. X. Kasperson, A. Luers, M. L. Martello, C. Polsky, A. Pulsipher, and A. Schiller. 2003. A framework for vulnerability analysis in sustainability science. Proceedings of the National Academy of Sciences 100 (14):8074-8079. http://dx.doi.org/10.1073/pnas.1231335100

U.S. Department of Agriculture Forest Service. 2005. B \& B Fire Recovery Project: Record of Decision. U.S. Department of Agriculture Forest Service, Sisters, Oregon, USA. [online] URL: https://scholarsbank.uoregon.edu/xmlui/bitstream/handle/1794/7103/ B $\% 26 \mathrm{~B}$ Fire Recovery Project ROD.pdf?sequence=1.

U.S. Department of Agriculture Forest Service and U.S. Geological Survey. 2009. Monitoring trends in burn severity. U.S. Department of Agriculture Forest Service and U.S. Geological Survey, Washington, D.C., USA. [online] URL: http://www.mtbs. gov/index.html.

Westerling, A. L., H. G. Hidalgo, D. R. Cayan, and T. W. Swetnam. 2006. Warming and earlier spring increase western U. S. forest wildfire activity. Science 313:940-943. http://dx.doi. org/10.1126/science.1128834

White, E. M. 2010. Woody biomass for bioenergy and biofuels in the United States - a briefing paper. General Technical Report PNW-GTR-825. U.S. Department of Agriculture Forest Service Pacific Northwest Research Station, Portland, Oregon, USA. [online] URL: http://www.fsl.orst.edu/lulcd/Publicationsalpha_files/ White pnw gtr825.pdf.

White, E. M., G. Latta, R. J. Alig, K. E. Skog, and D. M. Adams. 2013. Biomass production from the U.S. forest and agriculture sectors in support of a renewable electricity standard. Energy Policy 58:64-74. http://dx.doi.org/10.1016/j.enpol.2013.02.029

White, E. M., A. T. Morzillo, and R. J. Alig. 2009. Past and projected rural land conversion in the US at state, regional, and national levels. Landscape and Urban Planning 89(1-2):37-48. http://dx.doi.org/10.1016/j.landurbplan.2008.09.004

Winkler, R., D. R. Field, A. E. Luloff, R. S. Krannich, and T. Williams. 2007. Social landscapes of the Inter-mountain West: a comparison of 'Old West' and 'New West' communities. Rural Sociology 72(3):478-501. http://dx.doi.org/10.1526/003601107781799281

Winter, G., and J. S. Fried. 2000. Homeowner perspectives on fire hazard, responsibility, and management strategies at the wildland-urban interface. Society and Natural Resources 13 (1):33-49. http://dx.doi.org/10.1080/089419200279225 